\title{
Hubungan Antara Self-Confidence Mahasiswa dengan Kemampuan Pemahaman Matematis Dalam Perkuliahan Kapita Selekta Matematika IV
}

\author{
Angra Meta Ruswana ${ }^{1}$, Lala Nailah Zamnah ${ }^{2}$ \\ ${ }^{1,2}$ Pendidikan Matematika, Universitas Galuh, \\ 12angra.meta@gmail.com, ${ }^{2}$ nailah lala@yahoo.co.id
}

\begin{tabular}{l} 
INFO ARTIKEL \\
\hline Riwayat Artikel: \\
Diterima: 02-03-2018 \\
Disetujui: 20-03-2018 \\
\end{tabular}

\section{Kata Kunci:}

Self-Confidence,

Kemampuan,

Pemahaman Matematis,

Kapita Selekta,

Matematika IV,

\begin{abstract}
ABSTRAK
Abstrak: Penelitian ini bertujuan untuk menelaah hubungan antara self-confidence mahasiswa dengan kemampuan pemahaman matematis. Penelitian dilaksanakan di Program Studi Pendidikan Matematika Universitas Galuh dengan sampel penelitian mahasiswa tingkat 2 (semester IV) tahun akademik 2016/2017. Untuk mendapatkan data hasil penelitian, digunakan instrumen berupa tes kemampuan pemahaman matematis dan angket skala self-confidence. Analisis data menggunakan analisis korelasi dengan korelasi product moment. Hasil penelitian menunjukan bahwa terdapat hubungan antara self-confidence mahasiswa dengan kemampuan pemahaman matematis mahasiswa.

Abstract: The aim of the research is to explore the relationship between students' self confidence and mathematics comprehension. This research is conducted in mathematics education program in Galuh University. The participant of this research is the forth semester students in academic year 2016/2017. The data were gathered by using instruments such as mathematics comprehension and questionnaire for scaling the students' self confidence. The data were analyzed by using correlation of product moment. The result shows that there is positive correlation between students' self confidence and mathematics comprehension.
\end{abstract}

\section{A. LATAR BELAKANG}

Pendidikan merupakan salah satu aspek penting dalam kehidupan manusia. Salah satu fungsi pendidikan adalah menyiapkan generasi mendatang yang lebih baik daripada generasi saat ini. Semua upaya yang bertujuan untuk meningkatkan kemampuan matematik mahasiswa, tidak hanya berguna untuk memperoleh hasil belajar matematika yang tinggi, lebih dari itu sebagai bekal bagi mahasiswa untuk menjalani kehidupan bermasyarakat. Inilah konsep kehidupan matematika dan matematika untuk kehidupan. Seperti yang ditulis Turmudi (2008) bahwa mengetahui matematika mungkin menjadi kepuasan personal, bahkan suatu digdaya, yang menopang kehidupan sehari-hari secara meningkat umumnya bersifat matematika dan teknologi.

Salah satu disiplin ilmu yang mempunyai peranan penting dalam pendidikan dan dalam menentukan masa depan adalah matematika. Mengingat pentingnya matematika dalam ilmu pengetahuan serta kehidupan pada umumnya, maka matematika perlu dipahami oleh semua lapisan masyarakat terutama siswa sekolah formal. Hal ini dilandaskan dari asumsi bahwa penguasaan matematika akan menjadi salah satu sarana untuk mempelajari bidang studi lainnya, baik itu pada jenjang pendidikan yang sama maupun jenjang pendidikan yang lebih tinggi. Dengan demikian, mutu pembelajaran matematika pada semua jenjang pendidikan perlu untuk ditingkatkan agar tujuan dari pembelajarannya dapat tercapai secara optimal. Selain itu, hal terpenting yang harus dilakukan adalah membuat siswa menyadari akan pentingnya peranan dan fungsi matematika sehingga mereka menjadi lebih tertarik untuk mempelajari matematika.

Kurikulum Tingkat Satuan Pendidikan (KTSP) (Depdiknas, 2006) mengungkapkan tujuan diberikan mata pelajaran matematika di sekolah adalah agar para peserta didik memiliki kemampuan sebagai berikut :

1. Memahami konsep matematika, menjelaskan antar konsep dan mengaplikasikan konsep atau algoritma, secara luwes, akurat, efisien dan tepat dalam pemecahan masalah. 
2. Menggunakan penalaran pada pola dan sifat, melakukan manipulasi matematika dalam membuat generalisasi, menyusun bukti atau menjelaskan gagasan dan pernyataan matematika.

3. Memecahkan masalah yang meliputi kemampuan memahami masalah, merancang teknik matematika, menyelesaikan teknik dan menafsir solusi yang diperoleh.

4. Mengkomunikasikan gagasan dengan simbol, tabel, diagram atau media lain untuk memperjelas keadaan atau masalah.

5. Memiliki sikap menghargai kegunaan matematika dalam kehidupan yaitu memiliki rasa ingin tahu, perhatian dan minat dalam mempelajari matematika, serta sikap ulet dan percaya diri dalam pemecahan masalah.

Keberagaman latar belakang pendidikan pada mahasiswa Pendidikan Matematika FKIP Universitas Galuh menjadi salah satu faktor penghambat mahasiswa dalam mengikuti perkuliahan Kapita Selekta Matematika. Pada umumnya mahasiswa yang kesulitan belajar matematika saat di SD, SMP dan SMA berdampak pada rendahnya sikap dan kemampuan pemahaman matematis pada perkuliahan Kapita Selekta Matematika, sehingga masih memungkinkan adanya anggapan negatif mahasiswa terhadap matematika, dalam hal ini mata kuliah Kapita Selekta Matematika. Selain itu, masih banyak siswa yang mengalami kesulitan dalam mempelajari matematika karena kebanyakan dari mereka hanya sekedar menghafal konsepnya bukan memahaminya. Hal ini sejalan dengan pendapat Mettes (Irma, 2011) yang mengatakan bahwa siswa hanya mencontoh dan mencatat bagaimana cara menyelesaikan soal yang telah dikerjakan oleh gurunya.

Mata kuliah Kapita Selekta Matematika IV dalam struktur kurikulum Jurusan S1 Pendidikan Matematika FKIP Universitas Galuh diberikan kepada mahasiswa semester ke-4. Mata kuliah ini menjadi sangat penting karena memberikan manfaat dalam membekali mahasiswa pengetahuan dan keterampilan untuk menerapkan materi matematika dalam pembelajaran di SMA kelak. Mata kuliah ini membahas tentang materi matematika SMA dan pembelajarannya meliputi teorema sisa, limit dan turunan, integral, program linear, matriks, vektor, barisan dan deret, fungsi eksponen dan fungsi logaritma. Materi pada perkuliahan Kapita Selekta Matematika IV ini sebenarnya sudah mahasiswa peroleh ketika di jenjang pendidikan sebelumnya sehingga nilai akhir atau perolehan nilai yang diperoleh mahasiswa memuaskan, tetapi pada kenyataannya nilai yang diperoleh belum cukup memuaskan, masih ada yang memperoleh nilai $\mathrm{C}, \mathrm{D}$ bahkan E. Berikut ini disajikan data nilai akhir mahasiswa pada mata Kapita Selekta Matematika IV selama dua tahun disajikan pada Tabel 1.

TABEL 1

NILAI AKHIR MAHASIWA

\begin{tabular}{ccc}
\hline \multirow{3}{*}{$\begin{array}{c}\text { Nilai Akhir } \\
\text { (Huruf) }\end{array}$} & \multicolumn{2}{c}{$\begin{array}{c}\text { Banyak Mahasiswa pada } \\
\text { Tahun Akademik }\end{array}$} \\
\cline { 2 - 3 } & $2014 / 2015$ & $2015 / 2016$ \\
\hline A & 30 & 28 \\
B & 31 & 32 \\
C & 27 & 22 \\
D & 6 & 1 \\
E & 2 & 0 \\
\hline Jumlah & 96 & 83 \\
\hline
\end{tabular}

Pada tahun akademik 2014/2015 terdapat 35 (36,46 \%) mahasiswa yang memperoleh nilai C, D dan E dan pada tahun akademik 2015/2016 terdapat $23(27,71 \%)$ mahasiswa memperoleh nilai tersebut. Dengan nilai C dan D secara akademis mahasiswa dinyatakan telah lulus, namun nilai tersebut belum tentu menggambarkan kemampuan yang sesungguhnya. Berdasarkan analisis terhadap lembar jawaban soal ujian mahasiswa, masih terdapat kecenderungan jawaban benar untuk soal tentang konsep dasar, namun tidak demikian untuk soal penerapannya. Hal ini menunjukkan bahwa mahasiswa kurang menguasai konsep-konsep matematika SMA tersebut.

Berdasarkan fakta yang telah dikemukakan, hal ini menunjukkan bahwa kemampuan pemahaman matematis mahasiswa masih belum maksimal. Jadi salah satu permasalahan yang dihadapi saat ini adalah rendahnya kemampuan pemahaman matematis mahasiswa. Untuk menyelesaikan masalah ini, maka perlu mencari berbagai alternatif solusi yang baik agar kualitas pembelajaran matematika dapat diperbaiki, sehingga melalui kemungkinankemungkinan solusi yang dikembangkan diharapkan dapat membantu meningkatkan kemampuan pemahaman matematis.

Dalam kamus besar Bahasa Indonesia (Depdiknas, 2006) dijelaskan bahwa kata "pemahaman" berasal dari kata kerja "paham", yang berarti mengerti benar atau tahu benar. Seseorang dikatakan mengerti benar terhadap suatu konsep jika dapat menjelaskan kembali dan menarik kesimpulan terhadap konsep tersebut. Dalam proses pembelajaran, pemahaman terhadap suatu konsep ditunjukkan oleh kualitas hasil konstruksi terhadap konsep itu. Menurut Mayer (Kesumawati, 2011) pemahaman merupakan aspek fundamental dalam pembelajaran, sehingga model pembelajaran harus menyertakan hal pokok dari pemahaman.

Pemahaman berkaitan dengan penguasaan atau mengerti tentang sesuatu. Kemampuan pemahaman merupakan kemampuan paling mendasar yang harus dimiliki siswa karena kemampuan ini bisa menunjang siswa untuk 
mencapai kemampuan berpikir matematis lainnya. Siswa yang telah memahami konsep matematis akan lebih mudah dalam mempelajari ilmu matematika. Sumarmo (2003) menyatakan bahwa pemahaman matematis penting dimiliki siswa karena diperlukan untuk menyelesaikan masalah matematika, masalah dalam disiplin ilmu lain, dan masalah dalam kehidupan sehari-hari, yang merupakan visi pengembangan pembelajaran matematika untuk memenuhi kehidupan masa kini. Namun sebagian besar siswa masih belum mampu menyelesaikan soal matematika dengan baik karena kemampuan pemahamannya belum berkembang dengan baik. Sesuai yang diungkapkan oleh Hendrianan (2009) bahwa kemampuan pemahaman matematis siswa tidak berkembang sebagaimana mestinya.

Kemampuan pemahaman yang digunakan dalam penelitian ini adalah kemampuan pemahaman menurut Skemp (Sumarmo, 2010) yang menyatakan bahwa terdapat dua jenis kemampuan pemahaman, yaitu: 1) Pemahaman instrumental yang artinya hapal sesuatu secara terpisah atau dapat menerapkan sesuatu pada perhitungan rutin/sederhana, mengerjakan sesuatu secara algoritmik. Pada pemahaman ini siswa hanya menghapal rumus dan urutan pengerjaan dan algoritma saja; 2) Pemahaman relasional yang berarti dapat melakukan perhitungan secara bermakna pada permasalahan-permasalahan yang lebih luas, termuat skema atau struktur yang dapat digunakan pada penyelesaian yang memuat masalah yang lebih luas, dapat mengaitkan suatu konsep/prinsip lainnya dan sifat pemakaiannya lebih bermakna.

Selain kemampuan pemahaman masalah yang harus dimiliki oleh mahasiswa, terdapat juga soft skill yang harus dimiliki oleh siswa diantaranya adalah self-confidence. Menurut Afiatin dan Martaniah (1998), self confidence merupakan aspek kepribadian manusia yang berfungsi penting untuk mengaktualisasikan potensi atau kemampuan yang dimilikinya. Jika seseorang memiliki self confidence yang tinggi, maka ia akan selalu berusaha untuk mengembangkan segala sesuatu yang menjadi potensinya.

Self confidence seseorang terkait dengan dua hal yang paling mendasar dalam praktek hidup kita. Pertama, self confidence terkait dengan bagaimana seseorang memperjuangkan keinginannya untuk meraih sesuatu (prestasi atau kinerja). Kedua, self confidence terkait dengan kemampuan seseorang dalam menghadapi masalah yang menghambat perjuangannya.

Self confidence bukan merupakan sesuatu yang sifatnya bawaan tetapi merupakan sesuatu yang terbentuk dari interaksi. Untuk menumbuhkan self confidence diperlukan situasi yang memberikan kesempatan untuk berkompetisi. Seseorang belajar tentang dirinya sendiri melalui interaksi langsung dan komparasi sosial.

Jika mahasiswa memiliki self confidence, maka ia dapat sukses dalam belajar matematika. Self confidence mahasiswa pada matematika dan pada diri mereka sebagai mahasiswa yang belajar matematika akan memberikan peranan penting dalam pembelajaran dan kesuksesan mereka dalam matematika (Hannula, Maijala \& Pehkonen, 2004).

Rumusan masalah dalam penelitian ini adalah: Adakah hubungan antara self-confidence dan kemampuan pemahaman matematis. Tujuan dari penelitian ini adalah untuk menelaah hubungan antara self-confidence dan kemampuan pemahaman matematis mahasiswa.

\section{B. METODE PENELITIAN}

Penelitian ini bertujuan untuk menganalisis hubungan antara self-confidence dan kemampuan pemahaman matematis mahasiswa.

Penelitian ini Program Studi Pendidikan Matematika Universitas Galuh dengan sampel penelitian mahasiswa tingkat 2 (semester IV) tahun akademik 2016/2017 yang dipilih secara purposive.

Instrumen yang digunakan dalam penelitian ini adalah tes dan non-tes. Instrumen tes berupa soalsoal kemampuan pemahaman matematis yang berupa soal uraian (essay), sedangkan instrumen non-tes adalah angket skala self-confidence.

Teknik analisis data yang digunakan dalam penelitian ini adalah uji korelasi. Uji Korelasi antara self-confidence dengan kemampuan pemahaman matematis mahasiswa. Untuk melihat koefisien korelasi antara self-confidence dengan kemampuan pemahaman, maka kedua jenis data harus sama. Karena data kemampuan pemahaman matematis merupakan data interval, sedangkan self-confidence merupakan data ordinal, maka self-confidence harus ditransformasi terlebih dahulu menjadi data interval.

Setelah data self-confidence ditransformasi menjadi data interval, selanjutnya untuk melihat korelasi antara kemampuan pemahaman matematis dan self-confidence mahasiswa dengan menggunakan SPSS 16.0 for Windows.

\section{HASIL DAN PEMBAHASAN}

\section{Analisis Data}

Sebelum melakukan uji korelasi data, maka dilakukan uji normalitas data, seperti berikut :

$\mathrm{H}_{0} \quad$ : Data berdistribusi normal

$\mathrm{H}_{1} \quad$ : Data tidak berdistribusi normal

TABEL 2

UJI NORMALITAS

Kolmogorov-Smirnova

\begin{tabular}{crr}
\hline Statistic & df & \multicolumn{2}{c}{ Sig. } \\
\hline .177 & 34 & .009 \\
\hline .201 & 34 & .001 \\
\hline
\end{tabular}


Dari Tabel 2, terlihat bahwa nilai signifikansi uji Kolmogorov Smirnov pada kemampuan pemahman matematis adalah 0,09 dan nilai signifikansi uji Kolmogorov Smirnov pada selfconfidence adalah 0,01. Kedua kelas mempunyai nilai signifikansi kurang dari $\alpha$ yaitu 0,05. Maka dapat disimpulkan bahwa kedua kelas berdistribusi tidak normal. Karena kedua kelas berdistribusi tidak normal, selanjutnya dilakukan uji korelasi menggunakan uji statistik non-parametrik menggunakan uji Rank-Spearman dengan taraf signifikansi $\alpha$ yaitu 0,05 .

Hipotesis uji yang digunakan dalam uji korelasi adalah sebagai berikut:

$\mathrm{H}_{0}$ : Tidak terdapat hubungan antara selfconfidence mahasiswa dan kemampuan pemahaman matematis mahasiswa.

$\mathrm{H}_{1}$ : Terdapat hubungan antara self-confidence mahasiswa dan kemampuan pemahaman matematis mahasiswa.

TABEL 3

UJI KORELASI

\begin{tabular}{llcc}
\hline & & Self_confidence & Pemahaman \\
\hline Self_confidence & $\begin{array}{l}\text { Correlation } \\
\text { Coefficient }\end{array}$ & 1.000 & $.246^{*}$ \\
\cline { 2 - 4 } & Sig. (2-tailed) &. & .043 \\
\cline { 2 - 4 } & $\mathrm{N}$ & 68 & 68 \\
\hline Pemahaman & $\begin{array}{l}\text { Correlation } \\
\text { Coefficient }\end{array}$ & $.246^{*}$ & 1.000 \\
\cline { 2 - 4 } & Sig. (2-tailed) & .043 &. \\
\cline { 2 - 4 } & $\mathrm{N}$ & 68 & 68 \\
\hline
\end{tabular}

Dari tabel 3 terlihat bahwa hasil korelasi antara self-confidence dan kemampuan pemahaman matematis siswa adalah 0,246 dan nilai signifikansi sebesar 0,043. Harga korelasi $(r)$ yang diperoleh adalah 0,246 yang artinya tingkat hubungannya tergolong rendah. Nilai signifikansi sebesar 0,043 lebih kecil dari $\alpha=0,05$, maka dapat disimpulkan bahwa hipotesis nol yang menyatakan tidak terdapat hubungan antara selfconfidence mahasiswa dengan kemampuan pemahaman matematis mahasiswa ditolak. Dengan demikian, dapat disimpulkan bahwa terdapat hubungan antara self-confidence mahasiswa dengan kemampuan pemahaman matematis mahasiswa.

\section{Pembahasan}

Untuk melihat hubungan antara self-confidence dan kemampuan pemahaman matematis, dilakukan analisis korelasi pada data skor postes kemampuan pemahaman matematis dan skor angket akhir self-confidence. Sebelum data dianalisis, maka dilakukan dulu uji normalitas pada kedua data tersebut dan diperoleh hasil kedua data berdistribusi tidak normal. Karena kedua kelas berdistribusi tidak normal, maka selanjutnya dilakukan analisis korelasi menggunakan statistik non paramterik. Hasil dari analisis korelasi menunjukkan bahwa terdapat hubungan antara self-confidence dan kemampuan pemahaman matematis.

Nilai korelasi positif hal ini menunjukkan bahwa terdapat hubungan yang saling mempengaruhi antara self-confidence dan kemampuan pemahaman matematis mahasiswa. Artinya mahasiswa yang memperoleh skor tinggi pada postes kemampuan pemahaman matematis maka memiliki self-confidence yang tinggi, begitu juga sebaliknya mahasiswa yang memperoleh skor rendah pada postes kemampuan pemahaman matematis memiliki self-confidence yang rendah pula. Hal ini sesuai dengan pendapat Afiatin dan Martaniah (1998), self-confidence merupakan aspek kepribadian manusia yang berfungsi penting untuk mengaktualisasikan potensi atau kemampuan yang dimilikinya.

\section{SIMPULAN DAN SARAN}

Berdasarkan hasil penelitian dan pembahasan mengenai korelasi antara self-confidence dan kemampuan pemahaman matematis diperoleh simpulan bahwa terdapat hubungan antara selfconfidence mahasiswa dengan kemampuan pemahaman matematis mahasiswa.

Diharapkan untuk peneliti selanjutnya, bisa lebih dikembangkan lagi ruang lingkup dari variabel penelitian, agar bisa terlihat sejauh mana hubungan antara beberapa kemampuan matematis dengan selfconfidence dan juga melihat kemampuan mana yang lebih baik korelasinya dengan self-confidence. Selain itu juga bisa dicari hubungan antara kemampuan matematis dengan soft skill yang lainnya.

\section{UCAPAN TERIMA KASIH}

Penelitian ini bisa berjalan baik dan sesuai dengan harapan peneliti karena beberapa pihak yang mendukung baik secara moril mapun materil. Dalam hal ini peneliti sangat berterimaksih kepada beberapa pihak diantaranya adalah:

1. LPPM Universitas Galuh. Penelitian ini berada dalam program penelitian dan pengabdian kepada masyarakat di LPPM Universitas Galuh.

2. Rekan kerja saya, ibu Lala Nailah Z., M.Pd. Rekan terbaik dalam segala hal.

3. Mahasiswa program studi Pendidikan Matematika yang sudah bersedia meluangkan waktunya dalam memberikan kontribusi untuk terselenggaranya penelitian ini.

4. Semua pihak yang sudah membantu. 


\section{REFERENSI}

[1] Afiatin, T, Martaniah, SM. (1998). Peningkatan kepercayaan diri remaja melalui konseling kelompok. Jurnal Psikologi Nomor 6 Tahun III 1998. 66-79.

[2] Departemen Pendidikan Nasional. (2006). Kurikulum Tingkat Satuan Pendidikan. Jakarta: Pusat Kurikulum Balitbang Depdiknas.

[3] Hannula, M.S., Maijala, M \& Pehkonen, E. (2004). Development of Undersatnding Self-Confidence in Mathematics; Grade 5-8. Group for the Psychology of Mathematics Education, 3, 17-24.

[4] Hendriana, H. (2009). Pembelajaran dengan Pendekatan Metaphorical Thinking untuk Meningkatkan Kemampuan Pemahaman Matematik, Komunikasi matematik, dan Kepercayaan Diri Siswa Sekolah Menengah Pertama. Disertasi pada SPs UPI. Bandung: Tidak diterbitkan.

[5] Irma, A. (2011). Peningkatan Pemahaman dan Representasi matematis Siswa Sekolah Menengah Atas Melalui strategi Think-Talk-Write. Tesis pada SPs UPI. Bandung : Tidak diterbitkan.

[6] Kesumawati, N. (2011). Peningkatan Kemampuan Pemahaman, Pemecahan Masalah dan Disposisi Matematis Siswa SMP melalui Pendekatsn Matematika Realistik. Disertasi pada SPs UPI. Bandung: Tidak diterbitkan.

[7] Sumarmo, U. (2003). Pembelajaran Keterampilan Membaca Matematika Pada Siswa Sekolah Menengah. Makalah National Seminar On Science And Mathematics. FMIPA-UPI in cooperation with JICA. Dirjen Dikti Depdiknas.

[8] Sumarmo, U. (2010). Pendidikan Karakter, Berpikir dan Disposisi Logis, Kritis, dan Kreatif dalam Pembelajaran Matematika. Makalah pada perkuliahan Evaluasi Matematika 2011 SPS UPI: Tidak Diterbitkan.

[9] Turmudi. (2008). Landasan Filsafat dan Teori Pembelajaran Matematika (berparadigma Eksploratif dan Investigasi). Jakarta: Leuser Cita Pustaka. 